DOI: $10.2478 / \mathrm{v} 10014-008-0018-1$

Agrovoc descriptors: foods; product labelling; trade marks; provenance; quality labels; marketing; organoleptic analysis; income; value systems; motivation

Agris category code: E73; E50

COBISS Code 1.01

\title{
Attitudes towards private labels - example of a consumer sensory evaluation of food in Slovenia
}

\author{
Aleš KUHAR ${ }^{1}$ and Tanja TIČ ${ }^{2}$
}

Received: December 10, 2007; accepted August 5, 2008

Delo je prispelo 10. decembra 2007; sprejeto 5. avgusta 2008

\begin{abstract}
The study aims to extend the understanding of consumers' perception of private labelled food products in Slovenia. Consumer sensory test of sour gherkins was conducted in two experimental conditions where the effect of brand information on hedonic judgment was examined. The difference between private label and producer label products was especially scrutinized. Results show that consumers in Slovenia perceive private labels as a lower price alternative of comparable quality to producer brands. Disposable income and family size proved to have significant effect on propensity to buy private label food. Study confirms that the information about brand significantly affect consumer sensory judgment. The effect of assimilation has been confirmed also in the case of private label.
\end{abstract}

Key words: Private labels; Food; Consumer sensory evaluation

\section{IZVLEČEK}

\section{ODNOS DO TRGOVSKIH BLAGOVNIH ZNAMK - PRIMER SENZORIČNEGA VREDNOTENJA HRANE PRI POTROŠNIKIH V SLOVENIJI}

Raziskava poskuša poglobiti razumevanje percepcije trgovskih blagovnih znamk hrane pri slovenskih potrošnikih. Izvedeno je bilo senzorično vrednotenje vzorcev kislih kumaric pri dveh različnih vrstah eksperimentalnih razmer, kjer je bil ocenjevan učinek informacije o blagovni znamki na hedonično vrednotenje. Test je bil osredotočen na razlikovanje trgovskih blagovnih znamk in proizvajalčevih blagovnih znamk. Rezultati so pokazali, da slovenski potrošniki trgovske blagovne znamke vrednotijo kot cenovno ugodno alternativno izbiro primerljive kakovosti $v$ primerjavi $s$ proizvajalčevimi blagovnimi znamkami. Statistično značilni učinki nagnjenosti k izbiri trgovskih blagovnih znamk so bili potrjeni za dejavnike: razpoložljivi dohodek in velikost družine. Raziskava potrjuje hipotezo, da informacija o blagovni znamki statistično značilno vpliva na senzorično vrednotenje vzorcev pri potrošnikih. Učinek asimilacije je bil potrjen tudi pri trgovskih blagovnih znamkah.

1 University of Ljubljana, Biotechnical Faculty, Zootechnical Department, Groblje 3, SI-1230 Domžale, Slovenia, PhD., email: ales.kuhar@bfro.uni-lj.si.

2 Wageningen University, Food Technology Programme PO Box 81296700 EV, Wageningen, the Netherlands 
Ključne besede: trgovske blagovne znamke, hrana, senzorično ocenjevanje pri potrošnikih

\section{INTRODUCTION}

A food product is defined as an aggregation of attributes at different levels. According to Grunert et al. (2000) these are: search attributes (e.g. price, colour), experience attributes (e.g. taste and flavour) and credence attributes (e.g. health and safety). Notion of attributes itself, however, cannot explain all complexities of consumer choice, because they are considered as evaluative criteria. The latter are transposed to consumer perception through a process of interaction of product characteristics and personal socio-demographic, economic, psychographic, behavioural and cognitive determinants (Mowen, 1993; Alvensleben, 1997). Food selection and consumption are therefore a complex phenomenon influenced by a multitude of factors.

Individual socio-demographic and economic characteristics are commonly included when consumers are making a purchasing decision and they have to form quality expectations based on quality cues (Tuorila et al., 1998). Sensory properties of food, which have long been regarded as the main determinant of food selection, have a rather limited influence in that stage of process. Consumers therefore form their quality expectation for most of the food categories on extrinsic cues such as price, brand name, brand familiarity, advertisements, etc. The effects of extrinsic cues on consumer behaviour have been widely studied (for a review see Deliza and MacFie, 1996 or Schifferstein, 2001) and important effect on consumer expectations and hedonics sensory ratings has been confirmed. Price has been considered as a very important cue and received a great part of the research attention. However, in the literature (Jacoby et al., 1971) the theory that price is an objective cue, contrary to other factors being defined as subjective was established. In addition, for the regularity of brand's usage the most frequently read information about the foodstuff selected is important (Chernatony, 1991). Keller (2002) identified the following key functions of the brand for consumers: identification of origin; definition of responsibility of producer; risk reduction; search cost reduction and a virtual contract with producer (promise, guarantee). While Deliza and MacFie (1996) put the main focus of brand on informational cue. Consumers combine actual information from shopping environment with past experiences and use them to make purchase decision, but they strive for a "cognitive efficiency" and try to use minimum of information. As a result, they use a brand as a simplifier of a decision making process and hence the foundation of brand power.

According to the ownership, two types of brands are distinguished. Manufacturer brand (also producer brand, national brand), which is owned and coordinated by a producer and private label (also retailer's brand, own label) being owned and coordinated by a retailer or a buying group, as well as produced by a contracted manufacturer (Berthon et al., 1999). The presence of private labels nowadays is increasing rapidly and they are becoming one of the major factors in the developed food market from one side, and from the other are being considered as a significant 
threat to producers' brands and manufacturers' profitability (Baltas, 1997; Guerrero et al., 2000).

There is clear evidence from research work that non-sensory attributes of food (extrinsic cues) affect the sensory acceptability of a food product (Di Monaco et al., 2003). However, external attributes mainly affect purchase decision, while sensory attributes confirm liking of a product and therefore determine repeat purchase and loyalty.

Rather large research attention has been devoted to the effect of brand on overall liking and sensory evaluation of food (Deliza and MacFie, 1996; Cardello, 1994).

Schifferstein (2001) pointed out that the effect of a brand in the food choice is also largely dependant on individual characteristics of consumers and it is possible to distinguish them regarding to their sensitivity to brand. The effect of brand on consumer is well represented in scientific literature, however there are much less studies regarding the private labels. DelVecchio (2001) prepared a research focusing on the role of product category characteristics on private label perception and acceptability. He found that the consumer perception and penetration success of private label is driven by the segment complexity, quality variance, price and interpurchase time. The other relevant study aimed at determining what makes consumers more responsive to private label products (Baltas, 1997). The private label shopper has been identified as price sensitive but not promotion sensitive. High importance has been found regarding the familiarity with the product. Guerrero et al. (2000) have studied consumer attitude towards private labels. They founded that the Spanish consumers perceive private labelled products as reliable, different from producer brands and are good value for money. Cardello (1997) reports about negative stereotypes that affect private label purchase, however this might be dependent on the country and related to the retailer.

The present paper aims to extend the research area focusing on the direct comparison of the two brand types; namely private label and producer label. The main objective is to examine to which extent an extrinsic factor (information on brand) affects hedonic sensory judgment and whether there is a difference in respect to the type of brand.

The research focuses on food consumers in Slovenia. Food retailers have successfully acquired the strategy of private label and the concept is present in Slovenia for a decade with a particularly rapid growth during the last five years (Kuhar, 2005). Than at the beginning the leading retail chain intensively started introducing private label products as a mechanism to increase profitability. As their market share on the Slovenian grocery market was increasing (mainly through mergers and acquisitions), the national level of private label penetration has been accordingly risen. On the other hand, other players at the retail market started to introduce private label products, too. Meanwhile Slovenian food retail sector has become one of the most concentrated in Europe since the largest four retailers hold about $80 \%$ of the sector's turnover. Likely the most important factor for penetration growth of private label products in Slovenia is the level of retail sector 
concentration. At the same time promotion strategies have been also effectively conducted. As a result, the majority of domestic food processors now produce private label goods, but generally without the adequate sustenance strategies. Vertical dominance of retailers has consequently increased and is being considered as one of the main factors for radical reduction of food industry business performance.

\section{THE SURVEY METHODOLOGY}

The study was conducted in two consecutive stages. First, three focus groups were performed (24 participants), discussing food purchasing behaviour with special attention to private labelled products and to sour gherkins. Focus groups were composed from participants (fourteen females and ten males) of various age groups. At the final stage of each focus group a preliminary consumer sensory evaluation test was performed. The latter was intended to determine more precisely the survey protocol for the consumer sensory evaluation. Pickled gherkins were selected to serve as a research object since they offer a rather limited possibility for product differentiation. Furthermore, pickled gherkins are widely used in Slovenia and they were among the first sold food product under a private label.

Wording of consumers relating to the private labels was carefully studied from the focus groups discussions and applied when questionnaire was prepared as suggested by Malholtra and Birks (1999). In addition, the sensory evaluation protocol was fine-tuned following the propositions from Cardello and Shutz (2006).

The second part of the research was a consumer study with attitude questionnaire and sensory evaluation test involving 155 participants. Sampling of the participants was stratified according to the Slovenian population structure regarding gender and age (SORS, 2006).

Table 1. Basic demographic details of the sample Tabela 1. Osnovni demografski podatki o vzorcu

\begin{tabular}{|l|c|c|c|}
\hline \multicolumn{1}{|c|}{ Age group } & \multicolumn{2}{|c|}{ Gender } & Total \\
\hline & Male & Female & \\
\hline $16-27$ & $12.2 \%$ & $14.1 \%$ & $26.3 \%$ \\
\hline $28-40$ & $15.4 \%$ & $14.1 \%$ & $29.5 \%$ \\
\hline $41-55$ & $10.9 \%$ & $12.8 \%$ & $23.7 \%$ \\
\hline above 56 & $10.3 \%$ & $10.3 \%$ & $20.5 \%$ \\
\hline Total & $48.7 \%$ & $51.3 \%$ & $100.0 \%$ \\
\hline & & & \\
\hline \multicolumn{1}{|c|}{ Minimum } & Maximum & Average & Std. variation \\
\hline \multicolumn{1}{|c|}{17} & 81 & 41.37 & 15.67 \\
\hline
\end{tabular}

Survey was conducted in three locations (two shopping malls and a public library) in equal proportions. The experiments were done in purposely prepared sites with minimally required conditions for consumer sensory evaluations. First, the participants were given the questionnaire, which contained four parts: general food purchasing and eating behaviour; brands; sour gherkins and socio-demography. Each of them was let to fill-in the last part of it. Afterwards, they were asked to express their opinion about five samples of pickled gherkins on a seven-point hedonic scale. For the purposes of this experiment it was sufficient to ask consumers for simple judgment on general acceptability (level of likeness) of the product without indicating specific sensory characteristic 
Table 2. Experimental design

Tabela 2. Raziskovalni pristop

\begin{tabular}{|l|c|c|}
\hline \multicolumn{1}{|c|}{ Experimental conditions } & No. of subjects & Identification of samples \\
\hline B - blind & 155 & 3-digit code \\
\hline I - informed & 155 & brand name \\
\hline
\end{tabular}

It is believed that consumers make hedonic judgment considering the product as a whole and are generally not able to concentrate on singular sensory characteristics. Five brands of sour gherkins widely available on Slovenian market were included among which there were two private label products. In the first session samples were served in neutral plastic containers labelled with a random three digit sample code - so called "blind tasting". In the second session participants were serving themselves from the original packaging of sour gherkins and hence they were informed about the brand ("informed tasting"). Between the two tasting sessions consumers completed the remaining three parts of the questionnaire. The break between the sensory evaluation sessions was done to prevent "quiz" effect.

Results from the consumer questionnaire were processed using general descriptive statistics methods. In order to evaluate the effect of the tasting conditions on the hedonic ratings of pickled gherkins the difference between informed and blind ratings was calculated (I-B). Paired $t$-test was used to evaluate the statistical significance of the rating difference.

\section{RESULTS AND DISCUSSION}

Results from the consumer questionnaire mainly confirmed the evident trend of increasing private label food market shares in Slovenia. As much as $45 \%$ of the respondents classified into the "frequent buyer" of private label food ( $16.7 \%$ very frequently and $29.5 \%$ rather frequently). Only about one fifth of consumers claims "no buy" or "very rare buy" of private labels and the remaining one third buy it occasionally.

Figure 1 shows mean responses for private label product purchase frequency with the corresponding standard deviations $(\mathrm{CI}=95 \%)$. It is interesting for this research that processed vegetable comes as third following dairy products and salt, moreover the standard deviation of answers is the lowest. According to the results, for dairy products and salt around $20 \%$ of respondents always select private labelled product, whereas for processed vegetable almost half of the respondents claim occasional purchase and $30 \%$ often purchase. It is therefore possible to conclude that processed vegetable is a product group with high potentials for private label penetration. This is particularly true for the Slovenian market where the leading retailer is efficiently conducting the strategy of "differentiation prevention". Most of the processed vegetable (sour gherkins, red beetroot and sauerkraut) under the private label for this retailer is produced by the market leader and there is actually no difference to the products sold under the producer label. Beside limited quality difference, also other characteristics of the segment are stimulative: segment complexity is low and the inter-purchase time is short to medium. Beer has the lowest frequency with almost two thirds of the respondents claim no private label purchase, which has been expected. 


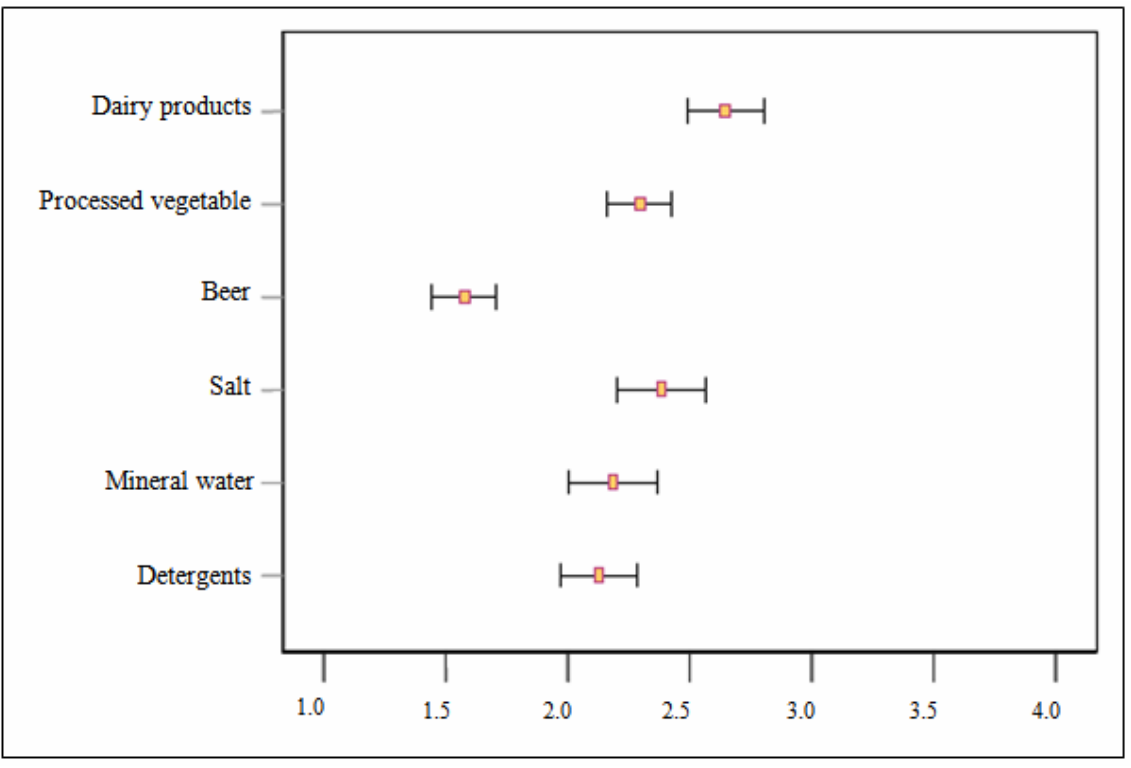

Figure 1. Private label product purchase frequency by product group

Slika 1. Pogostost nakupa trgovinske blagovne znamke po proizvodnih skupinah

The most obvious benefit to consumers afforded by private label is lower price. More than $90 \%$ of the respondents believe that the private label products are cheaper (Figure 2). When they were asked to compare overall product quality under producer label and equivalent private label the answer was not that uniform. As much as $49 \%$ of respondents stated that the quality of products is the same, but $45 \%$ believe the quality is lower. Therefore consumers strongly perceive private label products as a low-price alternative to producer label, however not all believe that they do not scarify on product quality. It seems that despite the lower perceived quality, Slovenian consumers accept the price-quality ratio of private label products. Assortment of private label products is shown to be inferior in comparison to the producer label since $61 \%$ of respondents stated the selection is worse. This is particularly true for the Slovenian market since retailers mainly offer simple substitutes to national brands also referred as first generation private labels. There is almost no private label differentiation; however this passive strategy still seems to be sufficient for exerting vertical chain domination and market power of Slovenian retailers. This is also to a great extent conditional with ineffective defensive strategies of Slovenian food processors. 


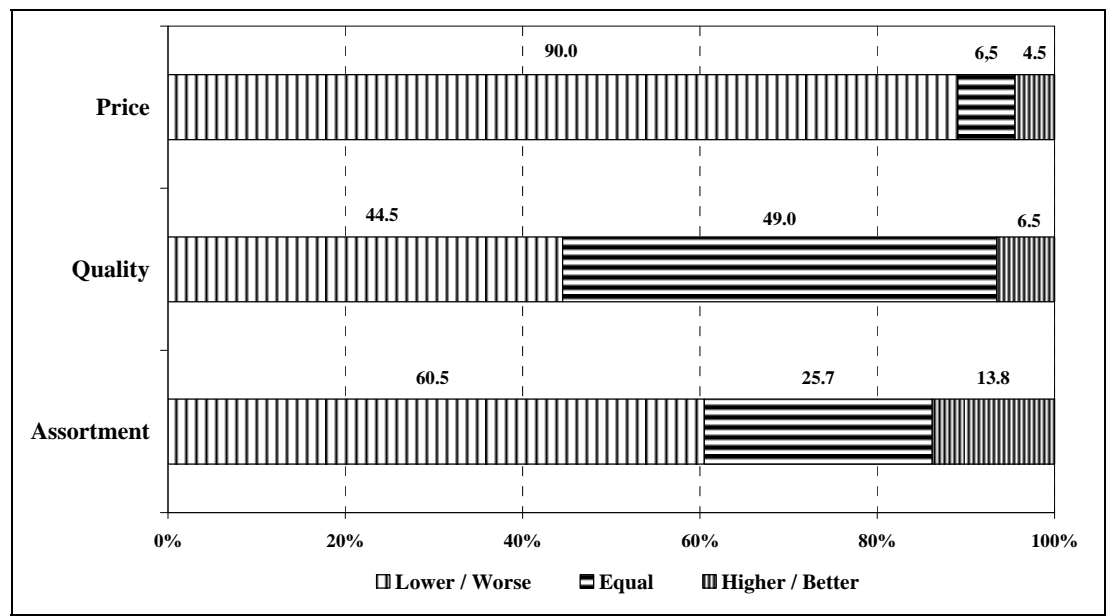

Figure 2. Comparisons of key product characteristics valuation for private label product vs. producer labelled products by respondents

Slika 2. Primerjava vrednotenja ključnih elementov proizvoda za trgovske blagovne znamke in proizvajalčeve blagovne znamke pri anketirancih

We have also attempted to discover whether the propensity to buy private labels is associated with demographic or socio-economic characteristics of consumers.

We found out that the gender, age and education are not significantly related to the reported frequency of private label purchase. This is in accordance with previous researches which also find rather weak association of propensity to buy private label and demographic characteristics of consumers (for review see: Baltas, 1997). Selfreported household disposable income has shown statistically significant effect on private label purchase frequency $(\mathrm{p}=0.01)$ with evident negative dependency (Gamma-0.215). Respondents in lower income groups are more frequent buyers of private label food products.

Table 3. Impact of the disposable household income on the frequency of private label purchase

Tabela 3. Vpliv razpoložljivega dohodka gospodinjstva na pogostost nakupa TBZ

\begin{tabular}{|l|c|c|c|c|c|}
\hline \multirow{2}{*}{ Income group } & \multicolumn{4}{|c|}{ Frequency of private label purchase } & \multirow{2}{*}{ Total } \\
\cline { 2 - 5 } & Very really & Occasionally & Frequently & $\begin{array}{c}\text { Very } \\
\text { frequently }\end{array}$ & \\
\hline$<650$ & $0.0 \%$ & $46.2 \%$ & $19.2 \%$ & $34.6 \%$ & $100.0 \%$ \\
\hline $650-1.500$ & $29.2 \%$ & $18.8 \%$ & $37.5 \%$ & $14.6 \%$ & $100.0 \%$ \\
\hline$>1.500-2.330$ & $14.9 \%$ & $46.8 \%$ & $27.7 \%$ & $10.6 \%$ & $100.0 \%$ \\
\hline$>2.330$ & $36.0 \%$ & $20.0 \%$ & $36.0 \%$ & $8.0 \%$ & $100.0 \%$ \\
\hline Total & $20.5 \%$ & $32.9 \%$ & $30.8 \%$ & $15.8 \%$ & $100.0 \%$ \\
\hline
\end{tabular}

$(\mathrm{p}=0.01 ; \mathrm{n}=146 ;$ Gamma -0.241$)$ 
Also the size of a household is found to be significantly related to private label product purchase frequency $(\mathrm{p}=0.04)$, however the frequency density is U-shaped. The smallest and the largest households are very likely among the most frequent buyers of private label products.

Table 4. Impact of the household size on the frequency of private label purchase Tabela 4. Vpliv velikosti gospodinjstva na pogostost nakupa TBZ

\begin{tabular}{|l|c|c|c|r|c|}
\hline \multirow{2}{*}{ Income group } & \multicolumn{3}{|c|}{ Frequency of private label purchase } & \multirow{2}{*}{ Total } \\
\cline { 2 - 5 } & Very really & Occasionally & Frequently & $\begin{array}{c}\text { Very } \\
\text { frequently }\end{array}$ & \\
\hline$<650$ & $16.0 \%$ & $28.0 \%$ & $24.0 \%$ & $32.0 \%$ & $100.0 \%$ \\
\hline $650-1,500$ & $21.4 \%$ & $37.5 \%$ & $33.9 \%$ & $7.1 \%$ & $100.0 \%$ \\
\hline$>1,500-2,330$ & $24.6 \%$ & $33.8 \%$ & $27.7 \%$ & $13.8 \%$ & $100.0 \%$ \\
\hline$>2,330$ & $10.0 \%$ & $10.0 \%$ & $30.0 \%$ & $50.0 \%$ & $100.0 \%$ \\
\hline Total & $21.2 \%$ & $32.7 \%$ & $29.5 \%$ & $16.7 \%$ & $100.0 \%$ \\
\hline
\end{tabular}

$(\mathrm{p}=0.039 ; \mathrm{n}=156)$

Furthermore preferred retail chain has a significant relation to the frequency of private label purchase. The consumers, who stated to do most of their shopping in the largest retail chain, show the largest propensity to buy private label. However, the chain does not have above the average share of private label in their offer. High penetration of this chain private label is rather a result of efficient marketing strategies and selection of private label producers.

Confirmative results regarding the private label perception of Slovenian consumers comes also from the aggregated descriptor named "Food attitude profile" where consumers were asked to choose the ultimate food purchasing determinant. The highest private label purchase frequency was found for the consumers that stated "Slovenian origin" as the most important factor when making food selection. More than half of them buy private label very frequently. This corresponds with the profile of leading retail chain which builds its position firmly on the ethnocentric strategies. The second most frequent buyers of private labels are, rather controversially, the respondents who stated that the producer is the most important determinant of product selection decision. This might be interpreted in two ways. Respondents either equalize private label with the producer (label), or another specificity of Slovenian market has effect here. Literally all products under the private label have full declaration of the producer, which might reduce risk related to private label selection. Negative relation is discovered for the consumer stating quality and health characteristics of food to be the main food selection determinants. They tend to buy private label "rarely" or "very rarely", whereas the distribution of respondents that prioritized price and taste in food selection is inconclusive-equally among categories of purchase frequency.

The results from the consumer evaluation are presented in the Tab. 5 which shows mean liking scores for five samples in two experimental conditions. The highest liking mean score in both experimental conditions has been given to the sample N2 which is the high quality product of the national market leader positioned in the 
gourmet segment. The liking score for this sample was significantly higher $(p=0.010)$ when the respondents knew the brand of the sample (informed tasting). In this case we can confirm an assimilation effect due to a positive image of the brand.

Table 5. Mean liking scores of hedonic sensory evaluation and effect of information on brand

Tabela 5. Srednje vrednosti hedoničnega senzoričnega vrednotenja in vpliv informacije o blagovni znamki

\begin{tabular}{|l|c|c|c|c|c|c|}
\hline Sample code & \multicolumn{2}{|c|}{ Mean liking score } & \multicolumn{2}{|c|}{ Standard deviation } & \multirow{2}{*}{ Mean Difference } & \multirow{2}{*}{ Significance (2-tailed) } \\
\hline & Blind & Informed & Blind & Informed & & .001 \\
\hline $\mathrm{N} 1$ & 4.56 & 5.08 & 1.627 & 1.557 & .526 & .000 \\
\hline $\mathrm{M} \mathrm{pl}$ & 4.46 & 5.02 & 1.703 & 1.483 & .561 & .088 \\
\hline $\mathrm{S} \mathrm{pl}$ & 4.08 & 3.80 & 1.852 & 1.709 & -.282 & .753 \\
\hline $\mathrm{D}$ & 3.17 & 3.12 & 1.914 & 1.829 & -.045 & .010 \\
\hline $\mathrm{N} 2$ & 5.07 & 5.42 & 1.533 & 1.455 & .346 & \\
\hline
\end{tabular}

The second ranked sample in blind testing was $\mathrm{N} 1$ and similarly the information about brand resulted in significantly higher mean ranking $(\mathrm{p}=0.001)$. Very close mean ranking has been revealed for the sample M-pl which is the private label "version" of the sample N1. There is virtually no other difference except the label design. This is also confirmed by almost negligible difference in mean scores under blind conditions. Respondents in the study therefore attested as rather reliable sensory evaluators. It is interesting, that also in the M-pl sample respondents show positive assimilation with statistically significant difference in mean liking $(\mathrm{p}=0.000)$. Actually, the informed-blind mean ranking difference was the largest for that sample. Obviously here consumers are aware of no difference between the producer brand and the private labelled product version. Another possible assimilation determinant might be the fact that the owner of the private label M-pl is the leading retail chain in Slovenia with aggressive private label marketing strategy and explicit ethnocentric positioning. It is rather different for the retail chain which is marketing the product under the sample code S-pl. Hedonic rating under informed conditions gave lower average liking score than blind tasting; however, the difference is not significant. The retailer chain is a subsidiary of a Global buying group and has only recently intensified the promotion strategy for private label segment. It has also rather different strategy regarding private label category composition than the leading retailer in Slovenia. Prevailing part of the private label products is sourced from the common supply chains of the corporation and are therefore not of Slovenian origin. We might therefore speculate that the perception of private label products in this retailer chain is characterized with some uncertainty having in mind expressed high preference of Slovenian consumers to domestic origin of food.

Information on the brand has no significant effect in the case of the D sample; however both average liking scores were lowest. The quality of this product 
obviously does not correspond to the expectations of Slovenian consumers. The brand has also lost image of reliable quality in the segment of processed vegetable.

\section{CONCLUSIONS}

Our study confirms that the information about brand can significantly affect consumers' hedonic sensory judgment of food. Consumer sensory judgment is therefore influenced by past experiences, familiarity, advertising etc. and preference is therefore influenced by more than the taste of food itself. When comparing the impact of experimental condition with respect to the type of brand, we observed the effect of assimilation also in the case of private label products which might be explained by responses from the attitudinal questions and actual market conditions in Slovenia. It has been noticed that consumers have a set of expectation related to a certain private label which is furthermore influenced by the perceived image of the retailer. In case where the retailer has a reputation on offering private labels produced by domestic leading manufacturers assimilation revealed has been positive. Opposite was discovered in the case of an international retailer where the assimilation has been negative, however not significant. It might be therefore inhered that consumers when making sensory evaluation are influenced similarly by the private label and producer label e.g. there is no difference regarding the type of label. These findings contribute to complex matter and have important implications for strategic brand management. Consumers do not perceive private labels as a "second class" label also in the case when the segment is non-diversified and only first generation private labels exist. Slovenian private label shoppers might be identified as a price-cautious but quality-sensitive. This highlights the necessity of permanent low price strategy for private label food and preventing differentiation from the producer brands in respect of perceived quality. On the other hand the food enterprises should strengthen the extrinsic cues of their products. This situation means that product and brand managers must begin to understand what drives the growing share given to store brands. And the acceptance of such brands means that the traditional view of store brands as a riskier purchase must merit re-evaluation. The concept of efficient consumer response where producer brand owners undertake to eschew price promotions in favor of consistent low prices in Slovenia seems an attractive proposition. Certainly, the retail chains, as the main customers of national brands, are inclined on securing a more consistent approach from manufacturers. However, as we have noticed seen in recent years, the power of supermarket buyers affects brand strategies very considerably. Consideration of the retailer bargaining power can jeopardise the decision to introduce a private label. When retailer bargaining power is high enough, it gives the distributor incentives to maintain its reputation by making the losses. As confirmed in our study, if the good is characterised by a low purchase frequency, significant bargaining power is not sufficient to ensure producer brand dominance. There is indeed a threshold under which a reputable brand is not viable, whatever the market condition. The consumer benefits, as the availability of a low-price product increases alternative choices. More importantly, consumers may prefer the guarantee offered by a familiar retail chain store on a cheaper product than the uncertainty and the risk of an unfamiliar 
brand. It has been the minor brands that have disappeared from the market at the expense of private label products.

Potentials for competitive advantage for producer brands therefore relies on superior quality and highly differentiated images via advertising, effective and continuous product innovation and creative design. National brand producers need to put the emphasis on strategies that sustain and justify the price premium over private labeled goods.

\section{REFERENCES}

Alvensleben, R. 1997. Consumer behaviour. In D. I. Padberg, C. Ritson, L. M. Albisu, Agrofood marketing. Wallingford: CAB Publishing, 209-224.

Baltas, G. 1997. Determinants of store brand choice: a behavioural analysis. Journal of Product and Brand Management, 6(5): 315-324.

Berthon, P., Hulbert, J.M., Pitt, L.F. 1999. Brand management prognostications. Sloan Management Review, 40(2): 53-65.

Cardello, A.V. 1994. Consumer expectations and their role in food acceptance. In: MacFie H.J.H., Thomson D.M.H., (eds). Measurement of food preferences. London: Blackie Academic and Professional, 253-297.

Cardello, A.V. 1997. Food stereotypes: prejudice in the pantry. Cereal Foods World, 42(4): 231-233.

Cardello A.V., Schutz H.G. 2006. Sensory science: measuring consumer acceptance. In: Hui Y.H. (ed.) Handbook of food science, technology, and engineering. Boca Raton, London, New York: Taylor \& Francis, CRC Press, 2(56)1-21.

Chernatony, L. 1991. Facilitating consumer choice decisions: the importance of branding cues. British Food Journal, 93(9): 50-56.

DelVecchio, D. 2001. Consumer perceptions of private label quality: the role of product category characteristics and consumer use of heuristics. Journal of Retailing and Consumer Services, 8(5): 239-249.

Deliza, R., MacFie, H. J. H. 1996. The generation of sensory expectation by external cues and its effect on sensory perception and hedonic ratings. A review. Journal of Sensory Studies. 11(2): 103-128.

Di Monaco, R., Cavella, S., Iaccarino, T., Mincione, A., Masi, P. 2003. The role of the knowledge of color and brand name on the consumer's hedonic ratings of tomato purees. Journal of Sensory Studies, 18(5): 391-408.

Guerrero, L., Colomer, Y., Guardia, M. D., Xicola J., Clotet, R. 2000. Consumer attitude towards store brands. Food Quality and Preference, 11(5): 387-395.

Grunert, K. G., Bech-Larsen, T., Bredahl, L. 2000. Three issues in consumer quality perception and acceptance of dairy products. International Dairy Journal, 10(8): $575-584$.

Jacoby, J., Olson, J. C., Haddock, R.A. 1971. Price, brand name, and product composition characteristics as determinants of perceived quality. Journal of Applied Psychology, 55(6): 570-579. 
Keller, K.L. (2002). Strategic brand management: Building, measuring, and managing brand equity. Prentice-Hall International, London. 788 p.

Kuhar, A. 2005. Ekonomski trendi v slovenski živilski industriji. 3. konferenca DAES, 29-43.

Malhotra, N.K., Birks, D.F. 1999. Marketing research. Harlow, Prentice Hall, 736.

Mowen, J. C. 1993. Consumer behaviour. New York: Macmillan Publishing.

Statistical office of Republic of Slovenia. 2006. Statistical yearbook 2005. Ljubljana, Statistical office of Republic of Slovenia, 454.

Schifferstein, H. N. J. 2001. Effects of product beliefs on product perception and liking. In: Frewer, L.J., E. Risvik and H.N.J. Schifferstein (eds.) Food, people and society: a European perspective of consumers' food choices. Berlin: Springer Verlag, 73-96.

Tuorila, H.M., Meiselman, H.L., Cardello, A.V., Lesher, L.L. 1998. Effect of expectations and the definition of products category on the acceptance of unfamiliar foods. Food Quality and Preference 9(6): 421-430. 